\title{
Illustrations
}

0.1 Police photograph of Osip Mandelstam taken on his arrest, 19384

0.2 Viktor Deni, "Comrade Lenin Is Sweeping the Scum off the Earth," poster, 19205

0.3 Agitational train decorated with satirical propaganda 8

0.4 Dmitrii Moor, "Christ suffered for you and showed you the way," Bezbozhnik u stanka 192312

0.5 Portrait of Anatoly Lunacharsky, 1920s 17

1.1 Anatoly Lunacharsky's Academy of Science identification document for 193220

1.2 Mice Burying the Cat, anonymous lubok, circa 172523

1.3 Vasily Perov, A Religious Procession at Easter, 186126

1.4 "Ukrainians and Russians have a common war cry ..." poster, 192032

1.5 "The Birth of the Cultural Revolution," Krokodil, 192836

1.6 Anatoly Lunacharsky sitting on Pegasus, Krokodil, 192937

1.7 "The Muses of the Narkompros," Krokodil, 192238

1.8 Anatoly Lunacharsky reading the satirical journal, Chudak, 192939

2.1 Signaly, 190646

2.2 "Moscow - The heart of Russia," Strely, 190647

2.3 "N. Satirikon Thanks the Bolsheviks for ..." Novyi satirikon, 191749

2.4 Viktor Deni, "The League of Nations," poster, 192051

2.5 Vladimir Mayakovsky in front of ROSTA windows, circa 192053

2.6 Vladimir Mayakovsky, "The Frenzied Polish Gentry Pounced on Russia Arrogantly," ROSTA window, 192155 
2.7 Vladimir Mayakovsky, "Famine Kills Mercilessly - Regardless of Party Membership," ROSTA window, 192156

2.8 Vladimir Mayakovsky, "Do We Need a Decree on Compulsory Smallpox Vaccination?" ROSTA window, 192157

2.9 Vladimir Mayakovsky, "From Now On Riding on the Engine Will Not Be Permitted," ROSTA window, 192159

2.10 Krokodil, 192263

2.11 "Perspectives for the 1939 Swimming Season," Krokodil, 193965

2.12 The Virgin Mary exclaims: “Why didn't I know ..." Krokodil, 192467

2.13 "Training for Easter," Krokodil, 192968

2.14 Krokodil, 193071

2.15 "We'll have to hire a few additional employees ..." Krokodil, 194072

3.1 Soviet clown and acrobat Vitalii Lazarenko, circa $1915 \quad 78$

3.2 Anti-Trotsky, satirical demonstration in Moscow, 193085

3.3 Antireligious satirical-parodic procession, 1920s 86

3.4 "Krokodil Evening," advertisement for a satirical propaganda show, 1920s 89

3.5 Artwork promoting one of the Sinyaya bluza troupes, early 1920s 90

3.6 Sinyaya bluza sketch featuring the victory of the Third International 91

3.7 Vsevolod Meyerhold's 1922 performance of The Magnanimous Cuckold 94

3.8 Collage by Lyubov Popova as set design sketch for Vsevolod Meyerhold's The Earth in Turmoil, 192395

4.1 Anatoly Lunacharsky and his second wife, silent film star Natalya Rozenel, 1930104

4.2 Anatoly Lunacharsky and Vladimir Mayakovsky, 1918105

4.3 Poster for The General Line (originally titled Old and New), 1929109

4.4 Poster for The Extraordinary Adventures of Mr. West ..., 1924110

4.5 Poster for Happiness, 1935117

4.6 Poster for Circus, 1936120

5.1 "Let him go on representing me that way ..." Krokodil, 1933128

5.2 Kazimir Malevich, An Englishman in Moscow, 1914130 
5.3 The pope dictates answers to prayers as Jesus Christ types, Krokodil, 1932131

5.4 Vassilii Vereshchagin, The Apotheosis of War, 1871133

5.5 "Monument to Imperialism," Krasnyi perets, 1924134

5.6 Viktor Deni, "Stalingrad," poster 1942135

5.7 Evgenii Khaldei, Nazi Helmets of No Further Use, 1945136

5.8 "In Our Collective Farm, There Is No Room for Priests and Kulaks," poster, 1930141

5.9 "A Thorny Path," Krokodil, 1926143

5.10 "The Path of Women," Krasnyi perets, 1923144

5.11 "Meshchanstvo Then and Now," Begemot, 1928147

5.12 "The Round Dance of Faith," Bezbozhnik u stanka, 1924149

5.13 "My poor dear, they have poisoned ..." Bezbozhnik u stanka, 1923152

5.14 "The Sermon on the Mountain," Bezbozhnik u stanka, 1923153

5.15 "Vessel of the Devil," Bezbozhnik u stanka, 1924154

5.16 "People Live ..." Bezbozhnik u stanka, 1925157

5.17 “Old Man's Riddle," Bezbozhnik u stanka, 1926158

5.18 Godless corner, 1920s 160

5.19 Viktor Deni, "Trotsky Slaying the Dragon of Counter-revolution," poster, 1920162

5.20 Trotsky disappears from May Day celebration, 1919164

5.21 Dmitrii Moor, "Be on Guard!," poster, 1921165

5.22 "We play, we play, but no one comes to hear," Krokodil, 1927167

5.23 "Lenin is dead, but his deeds live on ..." Krokodil, 1927168

5.24 "Unsatisfying Banquet," Krokodil, 1938169

5.25 Boris Efimov, "Fatherland," Izvestiya, 1938170

6.1 "You can't strike us down," Bezbozhnik u stanka, 1929175

6.2 Alexandre Deineka, The Order Is Restored, 1929183

6.3 "In the Northern Wilderness," Krokodil, 1936187

6.4 Pavel Korin, Portrait of the Kukryniksy (Kuprianov, Krylov, and Sokolov), 1957189

7.1 Leonid Sokov, Project to Construct Glasses for Every Soviet Citizen, 1976196 


\section{Colour Plates}

Colour plates follow page 190

Plate 1 Dmitrii Moor, Death to World Imperialism, poster, 1919

Plate 2 Vasily Pukirev, The Unequal Marriage, 1862

Plate 3 Dmitrii Moor, The People's Court, poster, 1919

Plate 4 "Emigrants - good riddance!" Bezbozhnik u stanka, 1923

Plate 5 Bezbozhnik u stanka, 1929

Plate 6 Aleksandr Rodchenko, collage illustrating Vladimir Mayakovsky's poem About This, 1923

Plate 7 "Peace and Liberty in Sovdepiya," White Army propaganda poster, circa 1919

Plate 8 "Marxist Evaluation," Krokodil, 1928

Plate 9 Nikolai Denisovsky, Petit Bourgeois Portrait, 1928

Plate 10 Vitaly Komar and Alexander Melamid, The Origins of Socialist Realism, 1982-83 